Article

\title{
Biosorption of Heavy Metals by the Bacterial Exopolysaccharide FucoPol
}

\author{
Patrícia Concórdio-Reis, Maria A. M. Reis and Filomena Freitas * \\ UCIBIO-REQUIMTE, Chemistry Department, NOVA School of Science and Technology, NOVA University \\ Lisbon, 2829-516 Caparica, Portugal; pc.reis@campus.fct.unl.pt (P.C.-R.); amr@fct.unl.pt (M.A.M.R.) \\ * Correspondence: a4406@fct.unl.pt; Tel.: +351-212948300
}

Received: 30 August 2020; Accepted: 24 September 2020; Published: 25 September 2020

\begin{abstract}
Despite the efforts for minimizing the usage of heavy metals, anthropogenic activities still generate high amounts of wastewater containing these contaminants that cause significant health and environmental problems. Given the drawbacks of the conventional physical and chemical methods currently used, natural biosorbents (microbial cells or their products) arise as promising environmentally friendly alternatives. In this study, the binding efficiency of the polysaccharide secreted by Enterobacter A47, FucoPol, towards lead $\left(\mathrm{Pb}^{2+}\right)$, cobalt $\left(\mathrm{Co}^{2+}\right)$, copper $\left(\mathrm{Cu}^{2+}\right)$ and zinc $\left(\mathrm{Zn}^{2+}\right)$ cations was demonstrated. FucoPol revealed a higher performance for the biosorption of $\mathrm{Pb}^{2+}$, with a maximum overall metal removal of $93.9 \pm 5.3 \%$ and a specific metal uptake of $41.1 \pm 2.3 \mathrm{mg} / \mathrm{gEPS}$, from a $\mathrm{Pb}^{2+}$ solution with an initial concentration of $10 \mathrm{mg} / \mathrm{L}$, by a $5 \mathrm{~g} / \mathrm{L}$ FucoPol solution. The overall metal removal decreased considerably $(\leq 31.3 \pm 1.6 \%)$ for higher $\mathrm{Pb}^{2+}$ concentrations (48 and $100 \mathrm{mg} / \mathrm{L}$ ) probably due to the saturation of FucoPol's binding sites. $\mathrm{Pb}^{2+}$ removal was also less efficient $(66.0 \pm 8.2 \%)$ when a higher FucoPol concentration $(10 \mathrm{~g} / \mathrm{L})$ was tested. $\mathrm{Pb}^{2+}$ removal efficiency of FucoPol was maximized at $\mathrm{pH} 4.3$, however, it was affected by lower $\mathrm{pH}$ values (2.5-3.3). Moreover, the FucoPol's sorption performance was unaffected (overall metal removal: $91.6-93.9 \%$ ) in the temperature range of $5-40{ }^{\circ} \mathrm{C}$. These findings demonstrate FucoPol's great potential for utilization as a biodegradable and safe biosorbent for treating waters and wastewaters contaminated with $\mathrm{Pb}^{2+}$.
\end{abstract}

Keywords: biosorption; biosorbent; heavy metals; Enterobacter A47; water/wastewater; exopolysaccharide; FucoPol

\section{Introduction}

Heavy metals are elements naturally found throughout the earth's crust. They have a high atomic number and a density at least 5 times higher than water $\left(1 \mathrm{~g} / \mathrm{cm}^{3}\right)[1,2]$. Despite being required for several biological processes (i.e., protein, nucleic acids, carbohydrate and lipid metabolism), they are also essential for our industry and daily life. Heavy metal sources include activities such as burning fossil fuels, mining, smelting and electroplating. They are also present in paints, batteries, metal products (e.g., ammunitions and pipes), cosmetics, electronic equipment, ceramics, fertilizers, pesticides, and wood preservatives [3,4]. Despite their widely utilization, heavy metals can cause serious toxicity issues in living organisms [3]. These metals are extremely poisonous and can eventually be lethal, since they inhibit essential metabolic pathways, cause oxidative stress and cellular damages, and can promote mutagenesis $[2,4,5] . \mathrm{Co}^{2+}$, for example, has only one biological function as a component of vitamin $\mathrm{B}_{12}$, nevertheless it can be toxic at high levels. $\mathrm{Co}^{2+}$ exposure might occur due to inhalation or ingestion of food and drinking water containing $\mathrm{Co}^{2+}$, and can cause neurological, cardiovascular, and endocrine problems such as cardiomyopathy, vision and hearing impairment, reversible hypothyroidism, and polycythemia $[6,7] . \mathrm{Cu}^{2+}$ is a trace nutrient 
essential for enzymatic activity and redox reactions due to its capacity to cycle between $\mathrm{Cu}^{2+}$ and $\mathrm{Cu}^{+}$. However, this transition to the reduced state can generate hydroxyl and superoxide radicals that can damage living cells [2,4]. $\mathrm{Cu}^{2+}$ exposure occurs by ingestion of water and can cause liver and kidney damage, anemia and irritation of the gastrointestinal track [1]. Although $\mathrm{Zn}^{2+}$ deficiency causes health problems, $\mathrm{Zn}^{2+}$ overexposure can cause cholesterol, anemia, nausea, vomiting, abdominal pain and lethargy [4]. $\mathrm{Pb}^{2+}$ is considered carcinogenic and highly toxic, it can bind and inactivate enzymes and proteins, substitute essential ions in the cells $\left(\mathrm{Ca}^{2+}, \mathrm{Mg}^{2+}, \mathrm{Fe}^{2+}\right.$, and $\left.\mathrm{Na}^{+}\right)$, and inhibit $\mathrm{Ca}^{2+}$ transport. Moreover, $\mathrm{Pb}^{2+}$ fastens the formation of reactive oxygen species (ROS) that causes oxidative stress and damages in living cells $[3,4,8] . \mathrm{Pb}^{2+}$ is absorbed and distributed into the human tissues after inhalation of $\mathrm{Pb}^{2+}$-contaminated dust or aerosols, and ingestion of contaminated water or food $[2,3] . \mathrm{Pb}^{2+}$ poisoning severely affects the nervous system, causing edema, encephalopathy, and brain damage [3]. Even low-level $\mathrm{Pb}^{2+}$ exposure is associated with liver/biliary injuries [9]; decreased kidney function and chronic kidney disease incidence [10]; and cardiovascular problems such as hypertension, electrocardiographic abnormalities, left-ventricular hypertrophy, peripheral arterial disease and cardiovascular disease mortality [11]. According to the US Environmental Protection Agency, the maximum concentration of $\mathrm{Cu}$ and $\mathrm{Zn}$ in drinking water is 1.3 and $5 \mathrm{mg} / \mathrm{L}$, respectively, a much higher value than of $\mathrm{Pb}(0.015 \mathrm{mg} / \mathrm{L})$, due to their lower toxicity to humans. However, $\mathrm{Cu}^{2+}$ and $\mathrm{Zn}^{2+}$ posed the greatest risk for aquatic living organisms from an urban lake in China [12].

Moreover, heavy metals are non-degradable and accumulate in the organisms, thus persisting and accumulating throughout the food chain $[2,4,13] . \mathrm{Pb}^{2+}$, for example, due to its environmental persistency, can impact the life course of individuals from the moment they are born. $\mathrm{Pb}^{2+}$ exposure during childhood and throughout the years, not only impacts their biological systems, but also has long-term ramifications, such as lower cognitive function and downward social mobility $[14,15]$. In view of this, the dispersion of heavy metals throughout both terrestrial and aquatic ecosystems has raised many ecological and health concerns.

Conventional physical and chemical methods have been implemented to remove metals from aqueous solutions, namely, ion exchange, reverse osmosis, chemical precipitation, chemical extraction, and electrochemical treatment [4]. However, they have some drawbacks, such as the difficulty for large scale implementation, the generation of undesirable by-products, high costs, and inefficiency to treat effluents contaminated with low metal concentrations $[4,16,17]$. Consequently, environmental biotechnology is focused on developing novel, attractive and economic alternatives to remove heavy metals from contaminated wastewaters. One of the most promising methods is the biosorption of heavy metals, which utilizes living or dead microorganisms, or products from their metabolism, such as polymers $[4,18]$.

Microbial cells are capable of binding and accumulating metal ions present in water, reducing their bioavailability. This biosorption phenomenon occurs due to the presence of biopolymers, rich in acidic functional groups, in the cellular structures that can bind metallic cations, independently from the cellular metabolism [4]. Biosorption of metal ions by polymers may involve different physical and chemical processes. Physical sorption occurs due to electrostatic and Van der Walls interactions, or due to the imbalance of metal concentration between the surface of the biosorbent and the solution $[4,19]$. Chemical mechanisms responsible for biosorption are complexation, chelation, coordination, microprecipitation, and ion exchange $[4,17]$.

Numerous extracellular polysaccharides (EPS) secreted by different microorganisms were reported to be effective in metal sequestration. For instance, the EPS produced by Paenibacillus jamilae [20], Bacillus firmus [21], Bacillus licheniformis KX657843 [18], Herbaspirillium sp. [22] and Paenibacillus peoriae TS7 [23] were capable of removing several heavy metals (e.g., $\mathrm{Zn}^{2+}, \mathrm{Pb}^{2+}, \mathrm{Ni}^{2+}, \mathrm{Cu}^{2+}, \mathrm{Cd}^{2+}, \mathrm{Co}^{2+}$, $\mathrm{Hg}^{2+}$ ) from aqueous systems. These reports suggest that the use of EPS is a promising solution for heavy metal sequestration and recuperation from water systems. The ability of EPS to adsorb metal cations is due to the presence of negatively charged functional groups (carboxyl, phosphoryl and 
hydroxyl groups) in these macromolecules' structures, which can establish electrostatic interactions and bind the positively charged metal ion [4,24]. Moreover, the use of microbial polysaccharides as biosorbents is advantageous since they are eco-friendly and non-toxic, and their production is easy and cost-effective [25]. Compared to the biosorption using living bacterial cells, metal biosorption with EPS has a reduced complexity and no metabolic interferences [4]. Moreover, living cells have nutritional requirements and are affected by abiotic stress factors [24].

FucoPol is an anionic EPS synthesized by the bacterium Enterobacter A47 [26]. This high molecular weight EPS is composed of fucose, galactose, glucose and glucuronic acid sugar residues (2.0:1.9:0.9:0.5 molar ratio), and the acyl groups acetyl, pyruvyl and succinyl, that represent $12.3 \mathrm{wt} \%$ of FucoPol's dry mass. FucoPol possesses a $\rightarrow 4)-\alpha$-L-Fucp-( $1 \rightarrow 4)-\alpha$-L-Fucp-( $1 \rightarrow 3)-\beta$-D-Glcp $(1 \rightarrow$ trimer backbone. The branches, present at position 3 of the first fucose, are composed of an $\alpha$-D-4,6-pyruvyl-Galp-( $1 \rightarrow 4)-\beta$-DGlcAp-( $1 \rightarrow 3)-\alpha$-D-Galp $(1 \rightarrow$ trimer, with two pyruvate caps in the terminal galactose, specifically at position C-4 and C-6 [27,28]. FucoPol was employed for the preparation of a bioactive silver nanocomposite [27] and as a coating agent for iron oxide magnetic nanoparticles (MNP). The use of these FucoPol-MNP was evaluated for human antibody purification [29] and as cell labeling nanoprobes for Magnetic Resonance Imaging [30]. The potential of using FucoPol as biosorbent for the removal of heavy metals from water streams was never explored.

This study focused on evaluating the performance of FucoPol for the biosorption of different heavy metals $\left(\mathrm{Pb}^{2+}, \mathrm{Co}^{2+}, \mathrm{Zn}^{2+}\right.$ and $\left.\mathrm{Cu}^{2+}\right)$. Considering the results, metal toxicity and prevalence, $\mathrm{Pb}^{2+}$ was selected for further tests. The effects of FucoPol dosage, initial metal concentration, $\mathrm{pH}$ and temperature were explored for $\mathrm{Pb}^{2+}$ removal, envisaging the optimization of the biosorption process.

\section{Materials and Methods}

\subsection{FucoPol Production, Purification and Characterization}

FucoPol was obtained by cultivation of the bacterium Enterobacter A47 (DSM 23139) in a 2 L bioreactor (BioStat B-plus, Sartorius, Germany) using mineral Medium $E^{*}$ with glycerol $(40 \mathrm{~g} / \mathrm{L}$ ) as carbon source, as described by Concórdio-Reis et al. [31]. FucoPol synthesis is triggered by imposing growth limiting conditions (i.e., oxygen and nitrogen limitation) concomitant with carbon availability during cultivation [31]. Thus, cultivation was performed under a fed-batch mode (feeding solution: Medium $\mathrm{E}^{*}$ supplemented with $200 \mathrm{~g} / \mathrm{L}$ of glycerol), with controlled temperature $\left(30.0 \pm 0.1{ }^{\circ} \mathrm{C}\right)$, $\mathrm{pH}(7.0 \pm 0.02)$ and dissolved oxygen concentration ( $10 \%$ of the air saturation). FucoPol was recovered from the cultivation broth after 4 days as previously described [27]. The procedure involved dilution of the broth with deionized water $(1: 10, v / v)$ to reduce viscosity, centrifugation $(13000 \times g, 45 \mathrm{~min})$ for cell removal, thermal treatment $\left(70^{\circ} \mathrm{C}, 1 \mathrm{~h}\right)$ of the cell-free supernatant to promote protein denaturation and, finally, centrifugation $(13,000 \times g, 45 \mathrm{~min})$ for removal of cell fragments and denatured proteins. For FucoPol purification, the low molecular weight compounds (salts, glycerol, proteins) were removed by diafiltration in a cross-flow module (Sartocon Slide Holder), using a membrane with a surface area of $100 \mathrm{~cm}^{2}$ and a $100 \mathrm{kDa}$ nominal molecular weight cut-off (Hydrosart ultrafiltration cassette, Sartorius) [27]. During diafiltration, deionized water was added to the retentate to facilitate the diffusion of low molecular weight solutes across the membrane. Finally, the module was operated in ultrafiltration mode, without water addition, to concentrate the treated supernatant $(3: 1, v / v)$, and the solution was freeze-dried to obtain the FucoPol (12.4 g).

FucoPol was characterized in terms of carbohydrate monomers and acyl groups composition, as well as total protein content and molecular mass distribution. For the determination of the sugar and acyl content, FucoPol $(1 \mathrm{~g} / \mathrm{L}, 5 \mathrm{~mL})$ was hydrolyzed with $0.1 \mathrm{~mL} 99 \%$ trifluoroacetic acid (TFA) at $120^{\circ} \mathrm{C}$ for $2 \mathrm{~h}$. The constituent monosaccharides were identified and quantified in the hydrolysate by HPLC using a Carbopac PA10 column (Thermo Scientific ${ }^{\mathrm{TM}}$ Dionex $^{\mathrm{TM}}$, Sunnyvale, CA, USA), equipped with an amperometric detector, as described by Concórdio-Reis et al. [31]. The analysis was performed at $30{ }^{\circ} \mathrm{C}$ with sodium hydroxide $(\mathrm{NaOH} 4 \mathrm{mM})$ as eluent, at a flow rate of $0.9 \mathrm{~mL} / \mathrm{min}$. The acid 
hydrolysates were also used for the identification and quantification of acyl substituents. The analysis was performed by HPLC with and Aminex HPX-87H $300 \times 7.8 \mathrm{~mm}$ (Biorad, Hercules, CA, USA), coupled to an infrared (IR) detector, using sulphuric acid $\left(\mathrm{H}_{2} \mathrm{SO}_{4} 0.01 \mathrm{~N}\right)$ as eluent, at a flow rate of $0.6 \mathrm{~mL} / \mathrm{min}$ and a temperature of $30^{\circ} \mathrm{C}$.

The protein content was determined by a modified Lowry method: $5.5 \mathrm{~mL}$ FucoPol solutions $(4.4 \mathrm{~g} / \mathrm{L})$ were mixed with $1 \mathrm{~mL} 20 \% \mathrm{NaOH}$ and incubated at $100{ }^{\circ} \mathrm{C}$, for $5 \mathrm{~min}$. After cooling on ice, $170 \mu \mathrm{L}$ of $\mathrm{CuSO}_{4} \cdot 5 \mathrm{H}_{2} \mathrm{O}(25 \% w / v)$ were added and the solution was agitated. Afterwards, the solution was centrifuged $(3500 \times g$, for $5 \mathrm{~min})$ and the optical density was measured at $560 \mathrm{~nm}$. Albumin (Sigma-Aldrich) solutions $(0.05-1.0 \mathrm{~g} / \mathrm{L})$ were used as protein standards. The average molecular weight $\left(\mathrm{M}_{\mathrm{w}}\right)$ was determined by size exclusion chromatography coupled with multi-angle light scattering (SEC-MALS), as described by Concórdio-Reis et al. [31]. Briefly, FucoPol solutions $(0.2 \mathrm{~g} / \mathrm{L})$ were dissolved in $0.1 \mathrm{M}$ Tris- $\mathrm{HCl}, \mathrm{NaCl}(0.2 \mathrm{M}), \mathrm{pH} 8.09$ buffer, which was also the SEC mobile phase. The SEC columns (PL aquagel-OH mixed $8 \mu \mathrm{m}, 30 \times 7.5 \mathrm{~mm}$ ) were equilibrated for $24 \mathrm{~h}$ before running the analysis at a flow rate of $0.7 \mathrm{~mL} / \mathrm{min}$ at $30^{\circ} \mathrm{C}$. In order to follow the purity and molecular mass distribution of the polysaccharide signals from MALS were recorded in parallel and treated with Astra (V 4.73.04). A d $n / \mathrm{dc}$ of $0.190 \mathrm{~mL} / \mathrm{g}$ was adopted to calculate the $\mathrm{M}_{\mathrm{W}}$ of the FucoPol.

\subsection{Preparation of Solutions}

Metal solutions (3-100 mg/L) of $\mathrm{Pb}^{2+}, \mathrm{Co}^{2+}, \mathrm{Zn}^{2+}$ and $\mathrm{Cu}^{2+}$ were prepared by dissolving the corresponding chloride salts in deionized water: $\mathrm{PbCl}_{2}$ (Sigma, 98\%), $\mathrm{CoCl}_{2} \cdot 6 \mathrm{H}_{2} \mathrm{O}$ (Panreac, 98\%), $\mathrm{CuCl}_{2} \cdot 2 \mathrm{H}_{2} \mathrm{O}$ (Merck, 99\%) and $\mathrm{ZnCl}_{2}$ (Scharlau, 95\%). FucoPol solutions were prepared by dissolving the freeze-dried polymer in deionized water at the appropriate concentrations according to the experiments $(1-10 \mathrm{~g} / \mathrm{L})$.

\subsection{Metal Biosorption Experiments}

To evaluate the ability of FucoPol for binding metals in aqueous systems, the method described by Maalej et al. [32] was performed, with some modifications. Equilibrium dialysis experiments were carried out by placing dialysis tubing (12-14 kDa MWCO membrane, ZelluTrans/Roth) containing the FucoPol solution $(5 \mathrm{~mL})$ in closed glass flasks with $200 \mathrm{~mL}$ of the appropriate metal solution. The flasks were placed in an orbital shaker ( $150 \mathrm{rpm}$ ) and kept at $21^{\circ} \mathrm{C}$, for $24 \mathrm{~h}$. Experiments were performed in triplicates. Controls were performed using deionized water in the dialysis tubing instead of the FucoPol solution. Samples of the metal solution $(2 \mathrm{~mL})$ were taken before and after the incubation period and the metallic ions were quantified by Inductively Coupled Plasma-Atomic Emission Spectroscopy (ICP-AES) (Ultima, Horiba Jobin-Yvon, France, equipped with a $40.68 \mathrm{MHz}$ RF generator, Czerny-Turner monochromator with $1.00 \mathrm{~m}$ (sequential) and autosampler AS500).

\subsection{Effect of Dosage, $\mathrm{pH}$ and Temperature on $\mathrm{Pb}^{2+}$ Biosorption Ability of FucoPol}

The effect of FucoPol dosage (1, 2,3,5 and $10 \mathrm{~g} / \mathrm{L}$ ) on FucoPol metal binding capacity towards $\mathrm{Pb}^{2+}$ was investigated. Moreover, various initial concentrations of $\mathrm{Pb}^{2+}$ solutions $(3,10,48$ and $100 \mathrm{mg} / \mathrm{L})$ were tested for a FucoPol concentration of $5 \mathrm{mg} / \mathrm{L}$. The effect of the $\mathrm{pH}$ value $(2.5,3.3$ and 4.3$)$ was also tested by adjusting the initial $\mathrm{pH}$ of the metal solution with $\mathrm{HCl}(1.0 \mathrm{M})$ or $\mathrm{NaOH}(1.0 \mathrm{M})$. The impact of temperature $\left(5,21,30\right.$ and $40^{\circ} \mathrm{C}$ ) in the metal removal abilities of FucoPol was also studied by keeping the orbital shaker with the flasks in an incubator set at different temperatures $\left(21-40^{\circ} \mathrm{C}\right)$ and in a cold chamber $\left(5^{\circ} \mathrm{C}\right)$.

\subsection{Calculations}

The metal removal efficiency $(M, \%)$ and the specific metal uptake $(q, \mathrm{mg} / \mathrm{gEPS})$ were calculated as follows:

$$
M=\frac{C f_{\text {Control }}-C f_{E P S}}{C f_{\text {Control }}} \times 100
$$




$$
q=\frac{(\mathrm{C} i-\mathrm{C} f)_{E P S}-(\mathrm{C} i-\mathrm{C} f)_{\text {Control }}}{\mathrm{m}_{\mathrm{EPS}}} \times V
$$

where $V(\mathrm{~mL})$ is the volume of the metal solution in the flask, $\mathrm{C} i$ and $\mathrm{C} f$ are the metal concentrations before and after equilibrium $(\mathrm{mg} / \mathrm{L})$, respectively, and $\mathrm{m}_{\mathrm{EPS}}$ represents the mass of FucoPol $(\mathrm{g})$.

\section{Results and Discussion}

\subsection{FucoPol Characterization}

Metal biosorption has been described for several EPS with different specificities and metal-binding capacities that can be attributed to differences in charge density, attractive interaction, and polymer conformation [20]. The biosorption performance of EPS varies significantly depending on their composition, as the properties of the active functional groups impact the biosorption mechanism [4]. Thus, biosorbent characterization is essential for a comprehensive analysis of the results (Table 1).

FucoPol is a high molecular weight $\left(4.4 \times 10^{6} \mathrm{Da}\right)$ polysaccharide secreted by the bacterium Enterobacter A47. It is mainly composed of neutral sugars, fucose, galactose and glucose, and the acidic sugar glucuronic acid (Table 1). The non-carbohydrate moiety comprises the acyl groups acetyl, pyruvyl and succinyl, which account for $12.3 \mathrm{wt} \%$ of FucoPol's mass. The presence of non-carbohydrate substituents and ionizable functional groups (carboxyl and hydroxyl groups), which are responsible for the binding capacity of biosorbents [24], in FucoPol's structure drove the interest in exploring its ability to bind heavy metal cations. Specifically, the presence of glucuronic acid residues, together with the pyruvyl and succinyl groups, that confer the biopolymer an anionic character, is relevant for its binding ability towards cations and positively charged molecules. FucoPol sample also has a protein content of $10.8 \%$, which was not completely removed during the purification procedures, probably due to their high $\mathrm{Mw}$ [27]. The presence of amine, sulfhydryl and carboxyl functional groups in proteins contribute to the overall negative charge of FucoPol [24]. On the other hand, metals can establish covalent or coordinative interactions with the sulfur- and nitrogen-containing ligands [4], which could also contribute to the metal biosorption capacity of FucoPol.

\subsection{Evaluation of the Metal-Binding Ability of FucoPol}

The metal-binding efficiency of FucoPol was tested by incubating FucoPol for $24 \mathrm{~h}$ in solutions containing $10 \mathrm{mg} / \mathrm{L}$ of $\mathrm{Pb}^{2+}, \mathrm{Cu}^{2+}, \mathrm{Zn}^{2+}$ or $\mathrm{Co}^{2+}$. The resulting metal removal efficiency $(M)$ and metal uptake $(q)$ values are presented in Figure 1.

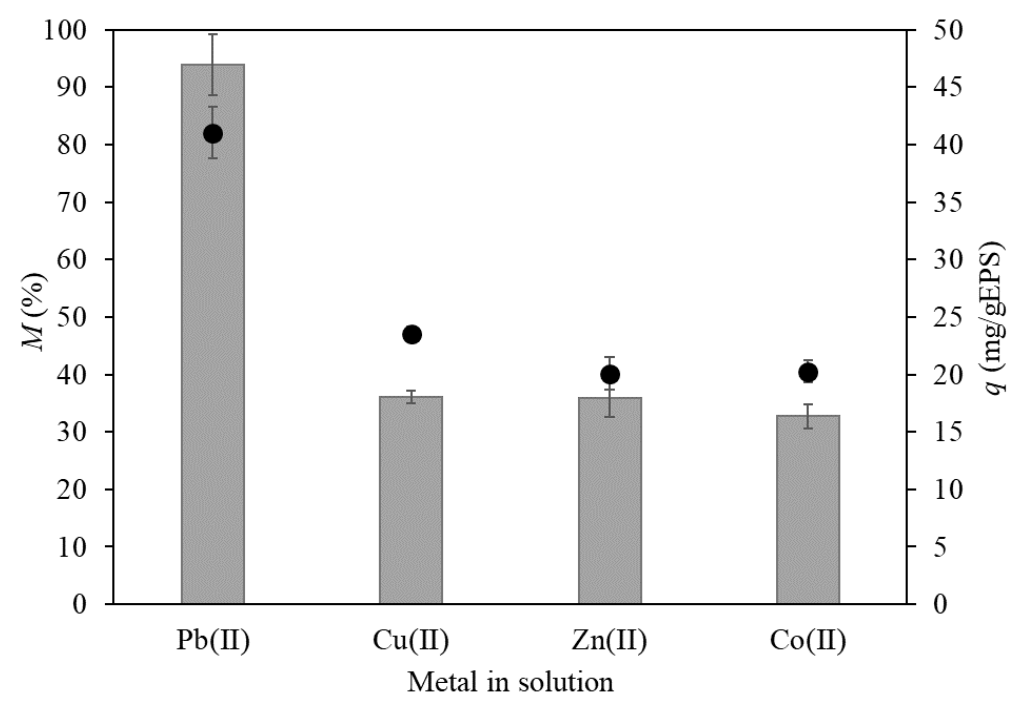

Figure 1. Biosorption of $\mathrm{Pb}^{2+}, \mathrm{Cu}^{2+}, \mathrm{Zn}^{2+}$ and $\mathrm{Co}^{2+}(\mathrm{Ci} 10 \mathrm{mg} / \mathrm{L})$ by FucoPol $(5 \mathrm{~g} / \mathrm{L})$ in terms of metal removal efficiency $(M, \square)$ and specific metal uptake $(q, \bullet)$ (temperature $21^{\circ} \mathrm{C}$, incubation time $24 \mathrm{~h}$ ). 
Table 1. Microbial EPS with biosorption capacity towards heavy metals (Man, mannose; Glc, glucose; Gal, galactose; Rha; rhamnose; Fuc, fucose: Fru, fructose; GlcA, glucuronic acid; GalA, galacturonic acid; Pyr, pyruvate; Succ, succinate; Ac, acetate).

\begin{tabular}{|c|c|c|c|c|c|}
\hline Organism & $\begin{array}{l}\text { Sugar Composition } \\
\text { (wt } \% \text { or Molar Ratio) }\end{array}$ & $\begin{array}{c}\text { Non-Sugar Residues } \\
\text { (wt } \%)\end{array}$ & $\begin{array}{l}M_{w} \\
(\mathrm{Da})\end{array}$ & $\begin{array}{l}\text { Bisorption Capacity } \\
\text { (mg/gEPS or \%) }\end{array}$ & References \\
\hline $\begin{array}{l}\text { Alteromonas macleodii subsp } \\
\text { fijiensis }\end{array}$ & $\begin{array}{c}\text { GlcA, Glc, Gal, Man and GalA } \\
(2.4: 1.6: 1.4: 1.1: 1.0)\end{array}$ & Protein $(4 \%)$ & n.a. & $\begin{array}{c}\mathrm{Pb}^{2+}: 316 \\
\mathrm{Zn}^{2+}: 75\end{array}$ & [33] \\
\hline Bacillus firmus MS-102 & $\begin{array}{c}\text { Glc, Fru, Man, Gal } \\
\text { (12.1:5.7:3.1:1.0) } \\
\text { Uronic acids (38 \%) } \\
\text { Man, Glc }(1.2: 1)\end{array}$ & $\operatorname{Pyr}(6.3 \%)$ & n.a. & $\begin{array}{l}\mathrm{Pb}^{2+}: 1103 \text { or } 98.3 \% \\
\mathrm{Cu}^{2+}: 860 \text { or } 74.9 \% \\
\mathrm{Zn}^{2+}: 722 \text { or } 61.8 \%\end{array}$ & [21] \\
\hline Bacillus sp. F19 & $\begin{array}{l}\text { Uronic acids }(37 \%) \\
\text { amino sugars }(0.5 \%)\end{array}$ & Protein $(16.4 \%)$ & n.a. & $\mathrm{Cu}^{2+}: 89.6$ & [34] \\
\hline Enterobacter A47 & $\begin{array}{c}\text { Fuc, Gal, Glc and GlcA } \\
(2.0: 1.9: 0.9: 0.5)\end{array}$ & $\begin{array}{c}\text { Protein }(10.8 \%) \\
\text { Ac, Pyr, Succ }(12.3 \%)\end{array}$ & $4.4 \times 10^{6}$ & $\begin{array}{l}\mathrm{Pb}^{2+}: 108.0 \text { or } 93.9 \% \\
\mathrm{Cu}^{2+}: 23.5 \text { or } 36.1 \% \\
\mathrm{Zn}^{2+}: 20.1 \text { or } 35.9 \% \\
\mathrm{Co}^{2+}: 20.3 \text { or } 32.7 \%\end{array}$ & This study \\
\hline Methylobacterium organophilum & $\begin{array}{l}\text { Gal, Man, Glu (3:2:2) } \\
\text { Uronic acids (12.4\%) }\end{array}$ & $\begin{array}{l}\text { Protein }(6.1 \%) \\
\text { Pyr }(5.1 \%) \\
\text { Ac }(0.6 \%)\end{array}$ & n.a. & $\begin{array}{l}\mathrm{Pb}^{2+}: 184.2 \\
\mathrm{Cu}^{2+}: 200.3\end{array}$ & [35] \\
\hline Paenibacillus jamilae & $\begin{array}{c}\text { Glc, Man, Gal, Fuc, Rha } \\
(54.6,25.6,12.9,3.8,3.1 \%) \\
\text { Uronic acids }(28.3 \%) \\
\text { Aminosugars }(2.8 \%)\end{array}$ & $\begin{array}{l}\text { Protein }(1.5 \%) \\
\text { Pyr }(8.7 \%) \\
\text { Acetyls }(4.13 \%)\end{array}$ & n.a. & $\begin{array}{l}\mathrm{Pb}^{2+}: 303.0 \\
\mathrm{Cu}^{2+}: 12.3 \\
\mathrm{Zn}^{2+}: 7.8 \\
\mathrm{Co}^{2+}: 20.5\end{array}$ & [20] \\
\hline Paenibacillus peoriae TS7 & Fru & - & n.a. & $\mathrm{Pb}^{2+}: 277.5$ & [23] \\
\hline $\begin{array}{c}\text { Pseudomonas aeruginosa } \\
\text { ATCC-10145 }\end{array}$ & $\begin{array}{l}\text { Neutral sugars }(30.6 \%) \\
\text { Uronic acids }(2.35 \%) \\
\text { Aminosugars }(0.78 \%)\end{array}$ & Protein $(27 \%)$ & n.a. & $\begin{array}{l}\mathrm{Pb}^{2+}: 79.7 \% \\
\mathrm{Cu}^{2+}: 87.4 \% \\
\mathrm{Zn}^{2+}: 80.6 \%\end{array}$ & [36] \\
\hline Pseudomonas stuteri AS22 & $\begin{array}{c}\text { Glc, Man, Lactyl rhamnose } \\
(1: 1.1: 0.7)\end{array}$ & Lactyl, acetyl and pyruvyl groups & $9.9 \times 10^{5}$ & $\begin{array}{c}\mathrm{Pb}^{2+}: 215.6 \\
\mathrm{Cu}^{2+}: 0.6 \\
\mathrm{Co}^{2+}: 1.4\end{array}$ & {$[32,37]$} \\
\hline $\begin{array}{c}\text { Rhizobium radiobacter } \mathrm{F} 2 \text { and } \\
\text { Bacillus sphaeicus } \mathrm{F} 6\end{array}$ & $\begin{array}{l}\text { Glc, Man, Rha, Gal } \\
\quad(10.0: 2.1: 1.3: 1.0)\end{array}$ & - & $4.79 \times 10^{5}$ & $\mathrm{~Pb}^{2+}: 189.3$ & [38] \\
\hline
\end{tabular}


FucoPol was able to adsorb all the tested metal species, although with different degrees of efficiency. Considering the overall metal removal efficiency, $M$, FucoPol had a higher affinity for $\mathrm{Pb}^{2+}$, since $93.9 \pm 5.3 \%$ of $\mathrm{Pb}^{2+}$ was removed from the solution. For the remaining tested cations, $\mathrm{Cu}^{2+}$, $\mathrm{Zn}^{2+}$ and $\mathrm{Co}^{2+}$, considerably lower values were obtained for $36.1 \pm 1.1 \%, 35.9 \pm 3.4 \%$ and $32.7 \pm 2.1 \%$, respectively (Figure 1). Considering the results, under the tested conditions, the preferential metal adsorption was $\mathrm{Pb}>>\mathrm{Cu}>\mathrm{Zn}>\mathrm{Co}$. When considering the overall specific metal uptake, $\mathrm{Pb}^{2+}$ also presented the highest value, $41.1 \pm 2.3 \mathrm{mg} / \mathrm{g}$, while $\mathrm{Co}^{2+}, \mathrm{Zn}^{2+}$ and $\mathrm{Cu}^{2+}$ had considerably lower $q$ values of $23.5 \pm 0.7 \mathrm{mg} / \mathrm{gEPS}, 20.1 \pm 1.4 \mathrm{mg} / \mathrm{gEPS}$, and $20.3 \pm 1.0 \mathrm{mg} / \mathrm{gEPS}$, respectively (Figure 1).

The different removal efficiency observed for $\mathrm{Pb}^{2+}$ in comparison with $\mathrm{Co}^{2+}, \mathrm{Zn}^{2+}$ and $\mathrm{Cu}^{2+}$ might be attributed to the different charge density of the ions, which is dependent on the cations ionic size [21]. The biosorptive capacity towards different metals can be speculated through the covalent index, calculated as $\mathrm{X}_{\mathrm{m}}{ }^{r}$, in which the electronegativity $\left(\mathrm{X}_{\mathrm{m}}\right)$ and ionic radius $(r)$ of the metals are considered. $\mathrm{Pb}^{2+}$ has the higher covalent index (6.41), followed by $\mathrm{Co}^{2+}(2.65), \mathrm{Cu}^{2+}(2.64)$ and finally $\mathrm{Zn}^{2+}(2.04)$ [39], which was the preferential sequence of specific metal uptake by FucoPol $(\mathrm{Pb}>>\mathrm{Co}$ $>\mathrm{Cu}>\mathrm{Zn}$ ). Furthermore, the FucoPol-Pb attraction might have been weaker than with other ions (higher repulsion due to the higher electronic density). This would lead to a less compact FucoPol structure in the presence of the metal. Hence, the same amount of $\mathrm{Pb}^{2+}$ occupied less surface area and less negatively charged functional groups than when the other metals were used [21]. This allowed that more $\mathrm{Pb}^{2+}$ could bind to FucoPol's molecule within the equilibrium period.

Several studies with other bacterial EPS reported a similar trend, wherein there was a better metal biosorption performance towards $\mathrm{Pb}^{2+}$ removal compared to other metals $\left(\mathrm{Cu}^{2+}, \mathrm{Zn}^{2+}, \mathrm{Co}^{2+}\right.$, $\left.\mathrm{Cd}^{2+}, \mathrm{Ni}^{2+}, \mathrm{Fe}^{2+}\right)$. Examples include the anionic EPS synthesized by P. stutzeri, P. jamilae and B. firmus, in which the order of metal uptake was $\mathrm{Pb}>\mathrm{Co}>\mathrm{Cu}, \mathrm{Pb}>>\mathrm{Cu}>\mathrm{Zn}>>\mathrm{Co}$ and $\mathrm{Pb}>\mathrm{Cu}>\mathrm{Zn}$, respectively $[20,21,32]$. However, the interaction between EPS and metals highly depends on the structure, composition and surface area of the biosorbent, as well as on the attractive forces and the conformation established between the EPS and the metal $[4,20]$, thus different results might be achieved depending on the characteristics of the EPS. In fact, contrasting results were reported for the EPS produced by $M$. organophilum and P. aeruginosa: $M$. organophilum EPS removed preferentially $\mathrm{Cu}^{2+}$ over $\mathrm{Pb}^{2+}\left(21 \%\right.$ and $18 \%$, respectively)[35], while P. aeruginosa EPS removed $87.4 \%$ of $\mathrm{Cu}^{2+}$, followed by $\mathrm{Zn}^{2+}$ $(80.6 \%)$ and $\mathrm{Pb}^{2+}(79.7 \%)$ [36]. Both EPS had less negative charged groups (e.g., uronic acids, pyruvate and acetate) in their composition than FucoPol and the EPSs that showed preferential removal of $\mathrm{Pb}^{2+}$ (Table 1).

Despite the increase in metal concentration inside the dialysis tubing observed in all tests, no insoluble species were formed, which indicated that FucoPol interacted with the metals in solution without chemically converting them into less soluble forms. As so, a biosorption mechanism, or a combination of several mechanisms, must be involved the FucoPol-metal interaction. Possible interaction mechanisms include microprecipitation, ion exchange, coordination, complexation, adsorption, chelation, and electrostatic interactions $[4,17]$.

Based on these results, it was clear that FucoPol has a good performance for $\mathrm{Pb}^{2+}$ sequestration. Lead poisoning causes serious health problems in the central nervous system, the kidneys, the gastrointestinal tract and the reproductive system [5]. Moreover, Tchounwou et al. [2] reported that up to $50 \%$ of $\mathrm{Pb}^{2+}$ adsorbed in adults was due to the ingestion of contaminated drinking water. Therefore, the subsequent experiments focused on the different factors that influenced the adsorption of $\mathrm{Pb}^{2+}$ by FucoPol, envisaging the optimization of its use as biosorbent.

\subsection{Effect of Initial Metal Concentration on the Pb ${ }^{2+}$-Binding Ability of FucoPol}

The metal-binding performance of FucoPol was evaluated in a range of different initial $\mathrm{Pb}^{2+}$ concentrations, 3 to $100 \mathrm{mg} / \mathrm{L}$ (Figure 2). This range was chosen since it was described that the conventional methods are inefficient for removal of $\mathrm{Pb}^{2+}$ concentrations below $100 \mathrm{mg} / \mathrm{L}[16,17]$. 


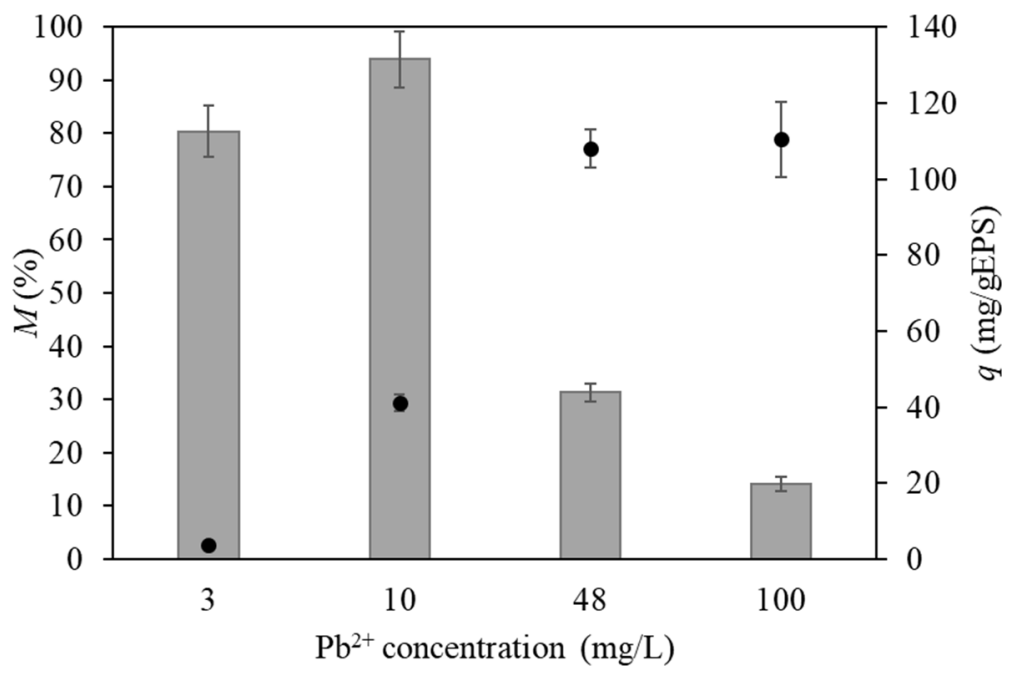

Figure 2. Specific metal uptake $(q, \bullet)$ and removal efficiency $(M, \square)$ by FucoPol $(5 \mathrm{~g} / \mathrm{L})$ using different initial $\mathrm{Pb}^{2+}$ concentrations (temperature $21^{\circ} \mathrm{C}$, incubation time $24 \mathrm{~h}$ ).

The results presented in Figure 2 proved that the initial concentration of $\mathrm{Pb}^{2+}$ had a significant effect on the $\mathrm{Pb}^{2+}$ uptake efficiency of FucoPol. For higher $\mathrm{Pb}^{2+}$ concentrations, metal uptake by FucoPol improved greatly. When the concentration of metal was augmented from $3 \mathrm{mg} / \mathrm{L}$ to $48 \mathrm{mg} / \mathrm{L}$, the specific $\mathrm{Pb}^{2+}$ uptake increased approximately 28 times, reaching a $q$ value of $108.0 \pm 5.0 \mathrm{mg} / \mathrm{gEPS}$. However, for metal concentrations of $100 \mathrm{mg} / \mathrm{L}$, the specific uptake had no further significant increase $(110.4 \pm 9.9 \mathrm{mg} / \mathrm{gEPS})$, probably due to the saturation of the binding sites of the polysaccharide $[4,23]$. For the highest metal concentrations tested ( 48 and $100 \mathrm{mg} / \mathrm{L}$ ), metal uptake reached a plateau value $\left(q_{\max }\right)$ and FucoPol was saturated, therefore the overall metal removal decreased drastically from the highest value of $93.8 \pm 5.3 \%$ achieved with $10 \mathrm{mg} / \mathrm{L}$ of $\mathrm{Pb}^{2+}$ to $14.1 \pm 1.3 \%$ with $100 \mathrm{mg} / \mathrm{L}$ of $\mathrm{Pb}^{2+}$. A similar trend was reported for the EPS produced by a mixed culture of $R$. radiobacter $\mathrm{F} 2$ and B. sphaeicus F6: when the initial $\mathrm{Pb}^{2+}$ concentration increased from 0.1 to $5 \mathrm{mg} / \mathrm{L}$, metal uptake increased 44.5 times, however, metal removal was maintained above $97 \%$ for concentrations in the range of $0.1-2 \mathrm{mg} / \mathrm{L}$ and decreased for $90 \%$ for higher concentrations [38].

\subsection{Effect of FucoPol Dosage on the Pb ${ }^{2+}$-Binding Ability of FucoPol}

The effect of the FucoPol dosage on the removal of $\mathrm{Pb}^{2+}$ from aqueous solutions $(10 \mathrm{mg} / \mathrm{L})$ was measured in terms of metal removal efficiency $(M)$ and specific metal uptake $(q)$, as disclosed on Figure 3.

As shown in Figure 3, the concentration of FucoPol used as biosorbent influenced the metal uptake $(q)$, as well as the overall metal removal efficiency $(M)$. In all experiments, an increase in FucoPol concentration led to an increase in metal removal. These results could be related to the fact that more binding sites were available to adsorb the metal ions in solution [23,40]. Maximal metal removal $(93.9 \pm 5.3 \%)$ was achieved when $5 \mathrm{~g} / \mathrm{L}$ of FucoPol were used, decreasing when a higher concentration $(10 \mathrm{~g} / \mathrm{L})$ was tested $(66.0 \pm 8.2 \%)$. Thus, it can be speculated that higher concentrations of FucoPol increase the occurrence of polymer-polymer interaction, reducing the availability of binding sites capable of metal sequestration [21]. Furthermore, higher concentrations of FucoPol cause an increase in viscosity [41], which may affect the diffusion of the metals, thus restraining their interaction with less accessible binding sites. Similar results were reported in the literature for other EPS. For example, for the EPS produced by P. aeruginosa, the use of an EPS concentration of $100 \mathrm{mg} / \mathrm{L}$ resulted in higher $\mathrm{Pb}$ removal rather than the higher dosages tested (1000-10000 mg/L) [36]. Also, for the EPS produced by P. peoriae TS7, a maximal $\mathrm{Pb}^{2+}$ removal of $89 \%$ was obtained with $0.5 \mathrm{~g} / \mathrm{L}$ of EPS, since both 
lower $(0.25 \mathrm{~g} / \mathrm{L})$ and higher concentrations (up to $2 \mathrm{~g} / \mathrm{L}$ ) led to a significant reduction in the removal efficiency [23].

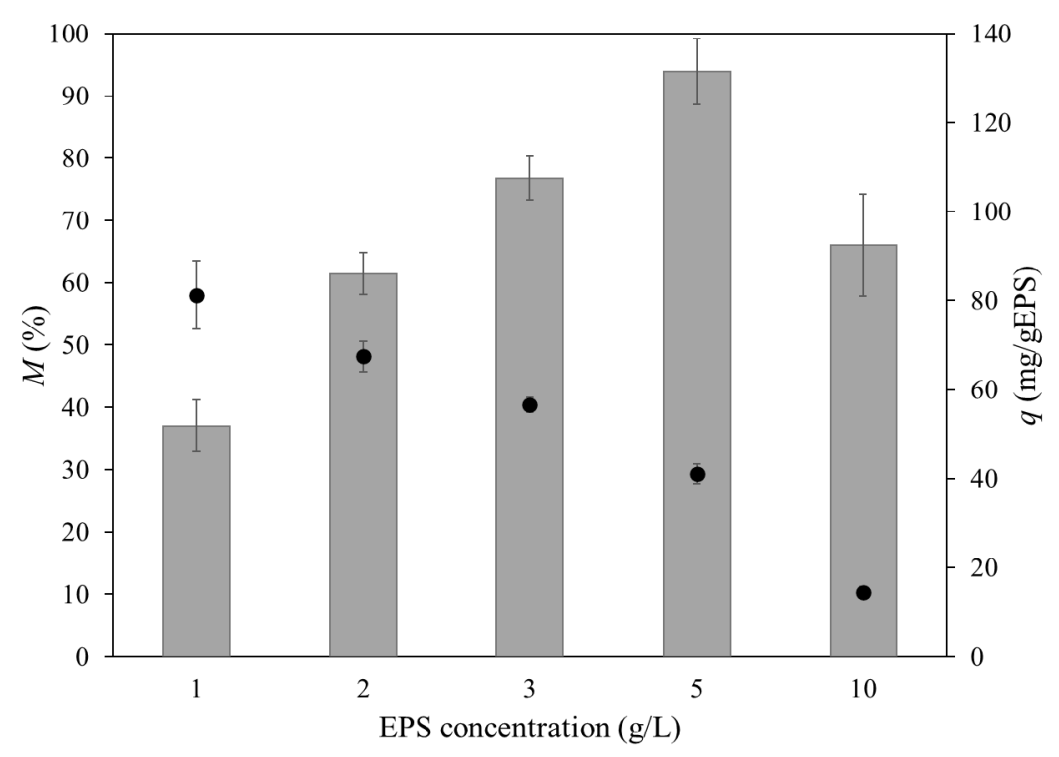

Figure 3. Removal of $\mathrm{Pb}^{2+}\left(C_{i} 10 \mathrm{mg} / \mathrm{L}\right)$ with different FucoPol concentrations. Results presented in terms of metal uptake $(q, \bullet)$ and removal efficiency $(M, \square)\left(\mathrm{pH} 4.3\right.$, temperature $21^{\circ} \mathrm{C}$, incubation time $\left.24 \mathrm{~h}\right)$.

An opposite trend was observed for the metal uptake, in which $q$ decreased with the increment of the FucoPol's concentration on the dialysis tubing (Figure 3). When the concentration of FucoPol rose from 1 to $10 \mathrm{mg} / \mathrm{L}$, the metal uptake decreased from $81.3 \pm 7.8 \mathrm{mg} / \mathrm{gEPS}$ to $14.4 \pm 1.2 \mathrm{mg} / \mathrm{gEPS}$. The different profiles of $M$ and $q$ shown in Figure 3 are in line with the results achieved for the biosorption of $\mathrm{Cu}^{2+}$ by the anionic EPS produced by Bacillus sp. F19. Indeed, an increase in EPS dosage from 500 to $1500 \mathrm{mg} / \mathrm{L}$ lead to an increase in removal efficiency from $71.2 \%$ to $91,2 \%$, and a reduction in metal uptake from 142 to $61 \mathrm{mg} / \mathrm{gEPS}$ [34]. Due to the differences in profiles under the same conditions, the subsequent studies were carried out with $5 \mathrm{mg} / \mathrm{L}$ of FucoPol, which was the concentration that maximized $M$.

\subsection{Effect of $\mathrm{pH}$ in $\mathrm{Pb}^{2+}$ Removal by FucoPol}

The $\mathrm{pH}$ affects the metal's solubility and the functional groups responsible for the metal-binding capacity since it determines their ionization state (protonated/deprotonated) [1,38,40,42,43]. The influence of this parameter in the metal-binding ability of FucoPol $(5 \mathrm{~g} / \mathrm{L})$ was evaluated for $\mathrm{pH}$ values between 2.5 to 4.3 (the latter was the $\mathrm{pH}$ value of the original metal solution), using an initial $\mathrm{Pb}^{2+}$ concentration of $10 \mathrm{mg} / \mathrm{L}$ (Figure 4). It was not possible to test higher $\mathrm{pH}$-values due to the occurrence of chemical precipitation of the metal above $\mathrm{pH} 6[1,44]$.

As shown in Figure 4, FucoPol had a higher removal efficiency at the maximal $\mathrm{pH}$ value tested (4.3). A reduction in $\mathrm{pH}$ ( 3.3 and 2.5) led to a considerable decrease in metal removal $(39.8 \pm 2.8 \%$ and $7.3 \pm 2.7 \%$, respectively). These results were probably due to the fact that the acidic groups of FucoPol were protonated, decreasing the negative charges available to interact with $\mathrm{Pb}^{2+}$ cations $[23,35]$. A similar trend was described for other anionic EPS, including the EPS produced by A. macleodii subsp fijiensis that demonstrated a low binding capacity at $\mathrm{pH}$ values below 4 , and optimal stable metal uptake values when the $\mathrm{pH}$ was between 4.5 and 6 [33]; and for the EPS produced by B. firmus MS-102, which optimal $\mathrm{Pb}^{2+}$ uptake was found at $\mathrm{pH} 4.5$ [21]. As can be seen in Table 1, these EPSs had polyanionic character due to their presence of uronic acids and acyl substituents in their composition. On the other hand, the EPS that did not present these groups in their composition seemed to be more efficient at neutral $\mathrm{pH}$. Examples include the EPS produced by P. peoriae, a fructose 
homopolysaccharide [23]; and the EPS produced by a mixed culture of R. radiobacter F2 and B. sphaeicus F6 that was only composed of neutral sugars (Table 1) [38].

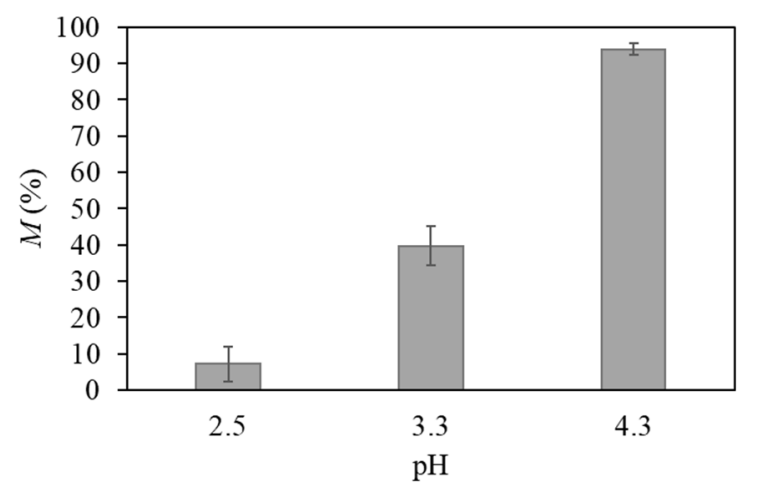

Figure 4. Effect of $\mathrm{pH}$ in $\mathrm{Pb}^{2+}$ removal efficiency by FucoPol $\left(C_{i} 10 \mathrm{mg} / \mathrm{L}\right.$, FucoPol concentration $5 \mathrm{mg} / \mathrm{L}$, temperature $21^{\circ} \mathrm{C}$, incubation time $24 \mathrm{~h}$ ).

\subsection{Effect of Temperature in $\mathrm{Pb}^{2+}$ Removal by FucoPol}

Considering that temperature fluctuations occur during the year and that it affects the metal uptake process [45], the effect of temperature in the $\mathrm{Pb}^{2+}$ removal abilities of FucoPol was explored in a range of 5 to $40{ }^{\circ} \mathrm{C}$ (Figure 5). In literature, temperatures above $35^{\circ} \mathrm{C}$ seemed to enhance biosorption due to an increase in surface activity and solute's kinetic energy. Moreover, higher temperatures promote an increase in the diffusion rate of metal though the external layer into the internal pores of the EPS, since its viscosity decreases [4].

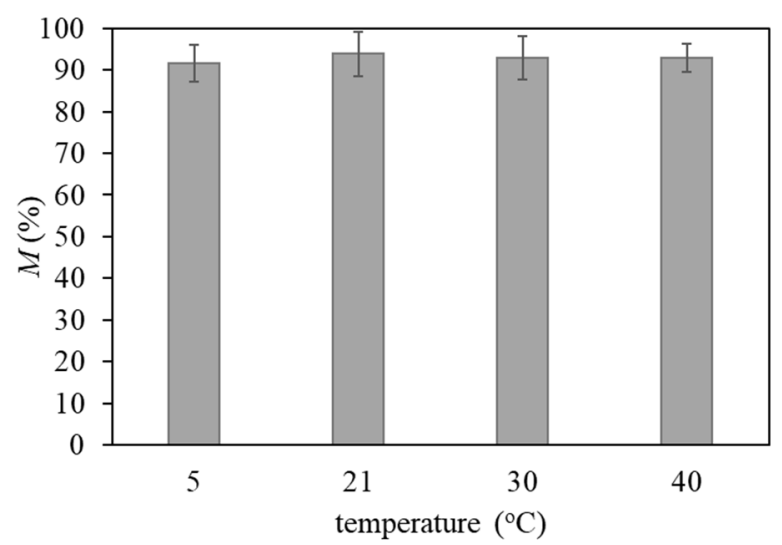

Figure 5. Effect of temperature in the $\mathrm{Pb}^{2+}$ removal efficiency by FucoPol $\left(C_{i} 10 \mathrm{mg} / \mathrm{L}\right.$, FucoPol concentration $5 \mathrm{~g} / \mathrm{L}, \mathrm{pH} 4.3$, incubation time $24 \mathrm{~h}$ ).

As Figure 5 demonstrates, the $\mathrm{Pb}^{2+}$ removal efficiency of FucoPol was statistically the same in the range of temperatures tested, thus showing that FucoPol is thermostable and suitable to be used at these temperatures. The influence of temperature was not investigated in the majority of the metal removal studies using EPS as biosorbents. Nevertheless, Lin and Harichund [22] reported a similar trend for the Paenibacillus sp. CH11 biosorbent, since $\mathrm{Pb}^{2+}$ removal by this protein-based exopolymer was not affected by temperature in the range from 4 to $45^{\circ} \mathrm{C}$. Also, the EPS produced by a mixed culture of $R$. radiobacter $\mathrm{F} 2$ and B. sphaeicus $\mathrm{F} 6$ was reported to be efficient within the temperature range of $5{ }^{\circ} \mathrm{C}$ to $35^{\circ} \mathrm{C}$ [38]. As so, FucoPol could be an effective alternative to be used in the removal of this metal from contaminated wastewaters without temperature control, despite the seasonal variations of this parameter. 


\subsection{Pb ${ }^{2+}$ Removal by FucoPol: Overall Assessment}

FucoPol revealed very promising $\mathrm{Pb}^{2+}$-binding ability, attaining high removal efficiency values (above $90 \%$, for an initial metal concentration of $10 \mathrm{mg} / \mathrm{L}$ ) at certain conditions, namely $\mathrm{pH}$ around 4.3 and temperatures up to $40^{\circ} \mathrm{C}$. Moreover, specific metal uptake values above $100 \mathrm{mg} / \mathrm{gEPS}$ were achieved for $\mathrm{Pb}^{2+}$ concentrations $\geq 48 \mathrm{mg} / \mathrm{L}$. The demonstrated $\mathrm{Pb}^{2+}$ removal ability of FucoPol is comparable to that of other natural biosorbents reported in the literature, both in terms of removal efficiency $(79.7-98.3 \%)[27,33]$ and specific metal uptake (16.6-1103 $\mathrm{mg} / \mathrm{g}$ biosorbent) $[21,46,47]$. The comparison of biosorbents' performance is difficult because different methodologies are implemented and different experimental conditions $(\mathrm{pH}$, temperature, metal and biosorbent concentration, presence of other contaminants) are used. Therefore, comparing results of different studies must be made with caution. Nevertheless, the values obtained suggest FucoPol might be suitable for the development of environmentally friendly and sustainable processes for the removal and recovery of lead from contaminated waters.

\section{Conclusions}

The present study demonstrated the capacity of bacterial EPS FucoPol for the biosorption different heavy metals from aqueous solutions. FucoPol was able to remove from solution all the metals tested, though with different removal efficiencies: $\mathrm{Pb}>>\mathrm{Cu}>\mathrm{Zn}>\mathrm{Co}$. Based on these results, metal toxicity and prevalence, $\mathrm{Pb}^{2+}$ removal by FucoPol was further studied. FucoPol was highly efficient for $\mathrm{Pb}^{2+}$ removal, even at low concentrations. Due to the excellent binding capacity under acidic $\mathrm{pH}$, FucoPol has great potential for use in $\mathrm{Pb}^{2+}$ removal from acidic wastewaters, such as those generated by batteries manufacturing. Additionally, FucoPol had high and stable binding activity in a temperature range of 5 to $40^{\circ} \mathrm{C}$, proving it can be used with high efficiency in wastewater treatment throughout the year, despite the seasonal temperature variations.

Author Contributions: Conceptualization, experimental methodology, formal analysis, writing-original draft preparation, P.C.-R.; writing-review and editing, supervision, M.A.M.R. and F.F. All authors have read and agreed to the published version of the manuscript.

Funding: This project was supported by the Applied Molecular Biosciences Unit (UCIBIO), which is financed by national funds from FCT/MCTES (UIDB/04378/2020). Patrícia Concórdio-Reis acknowledges FCT/MCTES for PhD grant SFRH/BD/131947/2017.

Conflicts of Interest: The authors declare no conflict of interest.

\section{References}

1. Abbas, S.H.; Ismail, I.M.; Mostafa, T.M.; Sulaymon, A.H. Biosorption of heavy metals: A review. J. Chem. Sci. Technol. 2014, 3, 74-102.

2. Tchounwou, P.B.; Yedjou, C.G.; Patlolla, A.K.; Sutton, D.J. Heavy Metal Toxicity and the Environment. In Molecular, Clinical and Environmental Toxicology; Luch, A., Ed.; Springer: Basel, Switzerland, 2012; Volume 101, pp. 133-164. ISBN 978-3-7643-8339-8.

3. Jaishankar, M.; Tseten, T.; Anbalagan, N.; Mathew, B.B.; Beeregowda, K.N. Toxicity, mechanism and health effects of some heavy metals. Interdiscip. Toxicol. 2014, 7, 60-72. [CrossRef] [PubMed]

4. Concórdio-Reis, P.; Freitas, F. Environmental Applications: Biopolymer Sorbents for Heavy Metal Removal. In Encyclopedia of Polymer Applications; CRC Press: Boca Raton, FL, USA, 2019; pp. 1069-1086.

5. Govind, P.; Madhuri, S. Heavy metals causing toxicity in animals and fishes. Res. J. Anim. Vet. Fish. Sci. 2014, 2, 17-23.

6. Paustenbach, D.J.; Tvermoes, B.E.; Unice, K.M.; Finley, B.L.; Kerger, B.D. A review of the health hazards posed by cobalt. Crit Rev Toxicol. 2013, 43, 316-362. [CrossRef] [PubMed]

7. Leyssens, L.; Vinck, B.; Van Der Straeten, C.; Wuyts, F.; Maes, L. Cobalt toxicity in humans-A review of the potential sources and systemic health effects. Toxicology 2017, 387, 43-56. [CrossRef]

8. Obeng-Gyasi, E. Sources of lead exposure in various countries. Rev. Environ. Health 2019, 34, 25-34. [CrossRef] 
9. Obeng-Gyasi, E.; Armijos, R.X.; Weigel, M.M.; Filippelli, G.; Sayegh, M.A. Hepatobiliary-related outcomes in US adults exposed to lead. Environments 2018, 5, 46. [CrossRef]

10. Harari, F.; Sallsten, G.; Christensson, A.; Petkovic, M.; Hedblad, B.; Forsgard, N.; Melander, O.; Nilsson, P.M.; Borné, Y.; Engström, G.; et al. Blood lead levels and decreased kidney function in a population-based cohort. Am. J. Kidney Dis. 2018, 72, 381-389. [CrossRef]

11. Lanphear, B.P.; Rauch, S.; Auinger, P.; Allen, R.W.; Hornung, R.W. Low-level lead exposure and mortality in US adults: A population-based cohort study. Lancet Public Health 2018, 3, e177-e184. [CrossRef]

12. Fu, Z.; Wu, F.; Chen, L.; Xu, B.; Feng, C.; Bai, Y.; Liao, H.; Sun, S.; Giesy, J.P.; Guo, W. Copper and zinc, but not other priority toxic metals, pose risks to native aquatic species in a large urban lake in Eastern China. Environ. Pollut. 2016, 219, 1069-1076. [CrossRef]

13. Kim, H.S.; Kim, Y.J.; Seo, Y.R. An Overview of Carcinogenic Heavy Metal: Molecular Toxicity Mechanism and Prevention. J. Cancer Prev. 2015, 20, 232-240. [CrossRef] [PubMed]

14. Reuben, A.; Caspi, A.; Belsky, D.W.; Broadbent, J.; Harrington, H.; Sugden, K.; Houts, R.M.; Ramrakha, S.; Poulton, R.; Moffitt, T.E. Association of childhood blood lead levels with cognitive function and socioeconomic status at age 38 years and with IQ change and socioeconomic mobility between childhood and adulthood. JAMA 2017, 317, 1244-1251. [CrossRef] [PubMed]

15. Obeng-Gyasi, E. Lead exposure and oxidative stress-A life course approach in US adults. Toxics 2018, 6, 42. [CrossRef] [PubMed]

16. Mehta, S.K.; Gaur, J.P. Use of Algae for Removing Heavy Metal Ions from Wastewater: Progress and Prospects. Crit. Rev. Biotechnol. 2005, 25, 113-152. [CrossRef]

17. Wang, J.; Chen, C. Biosorbents for heavy metals removal and their future. Biotechnol. Adv. 2009, 27, 195-226. [CrossRef]

18. Biswas, J.K.; Banerjee, A.; Sarkar, B.; Sarkar, D.; Sarkar, S.K.; Rai, M.; Vithanage, M. Exploration of an Extracellular Polymeric Substance from Earthworm Gut Bacterium (Bacillus licheniformis) for Bioflocculation and Heavy Metal Removal Potential. Appl. Sci. 2020, 10, 349. [CrossRef]

19. Brinza, L.; Dring, M.J.; Gavrilescu, M. Marine micro and macro algal species as biosorbents for heavy metals. Environ. Eng. Manag. J. EEMJ 2007, 6, 237-251. [CrossRef]

20. Morillo Pérez, J.A.; García-Ribera, R.; Quesada, T.; Aguilera, M.; Ramos-Cormenzana, A.; Monteoliva-Sánchez, M. Biosorption of heavy metals by the exopolysaccharide produced by Paenibacillus jamilae. World J. Microbiol. Biotechnol. 2008, 24, 2699-2704. [CrossRef]

21. Salehizadeh, H.; Shojaosadati, S.A. Removal of metal ions from aqueous solution by polysaccharide produced from Bacillus firmus. Water Res. 2003, 37, 4231-4235. [CrossRef]

22. Lin, J.; Harichund, C. Production and characterization of heavy-metal removing bacterial bioflocculants. Afr. J. Biotechnol. 2012, 11, 9619-9629. [CrossRef]

23. Fella-Temzi, S.; Yalaoui-Guellal, D.; Rodriguez-Carvajal, M.A.; Belhadi, D.; Madani, K.; Kaci, Y. Removal of lead by exopolysaccharides from Paenibacillus peoriae strainTS7 isolated from rhizosphere of durum wheat. Biocatal. Agric. Biotechnol. 2018, 16, 425-432. [CrossRef]

24. Gupta, P.; Diwan, B. Bacterial Exopolysaccharide mediated heavy metal removal: A Review on biosynthesis, mechanism and remediation strategies. Biotechnol. Rep. 2017, 13, 58-71. [CrossRef] [PubMed]

25. Rahim, M.; Mas Haris, M.R.H. Application of biopolymer composites in arsenic removal from aqueous medium: A review. J. Radiat. Res. Appl. Sci. 2015, 8, 255-263. [CrossRef]

26. Freitas, F.; Alves, V.D.; Torres, C.A.V.; Cruz, M.; Sousa, I.; Melo, M.J.; Ramos, A.M.; Reis, M.A.M. Fucose-containing exopolysaccharide produced by the newly isolated Enterobacter strain A47 DSM 23139. Carbohydr. Polym. 2011, 83, 159-165. [CrossRef]

27. Concórdio-Reis, P.; Pereira, C.V.; Batista, M.P.; Sevrin, C.; Grandfils, C.; Marques, A.C.; Fortunato, E.; Gaspar, F.B.; Matias, A.A.; Freitas, F.; et al. Silver nanocomposites based on the bacterial fucose-rich polysaccharide secreted by Enterobacter A47 for wound dressing applications: Synthesis, characterization and in vitro bioactivity. Int. J. Biol. Macromol. 2020, 163, 959-969. [CrossRef] [PubMed]

28. Guerreiro, B.M.; Freitas, F.; Lima, J.C.; Silva, J.C.; Dionísio, M.; Reis, M.A.M. Demonstration of the cryoprotective properties of the fucose-containing polysaccharide FucoPol. Carbohydr. Polym. 2020, 245, 116500. [CrossRef]

29. Dhadge, V.L.; Morgado, P.I.; Freitas, F.; Reis, M.A.; Azevedo, A.; Aires-Barros, R.; Roque, A.C.A. An extracellular polymer at the interface of magnetic bioseparations. J. R. Soc. Interface 2014, 11, 20140743. [CrossRef] 
30. Palma, S.I.C.J.; Rodrigues, C.A.V.; Carvalho, A.; Morales, M.d.P.; Freitas, F.; Fernandes, A.R.; Cabral, J.M.S.; Roque, A.C.A. A value-added exopolysaccharide as a coating agent for MRI nanoprobes. Nanoscale 2015, 7, 14272-14283. [CrossRef]

31. Concórdio-Reis, P.; Pereira, J.R.; Torres, C.A.V.; Sevrin, C.; Grandfils, C.; Freitas, F. Effect of monoand dipotassium phosphate concentration on extracellular polysaccharide production by the bacterium Enterobacter A47. Process Biochem. 2018, 75, 16-21. [CrossRef]

32. Maalej, H.; Hmidet, N.; Boisset, C.; Buon, L.; Heyraud, A.; Nasri, M. Optimization of exopolysaccharide production from Pseudomonas stutzeri AS22 and examination of its metal-binding abilities. J. Appl. Microbiol. 2015, 118, 356-367. [CrossRef]

33. Loaëc, M.; Olier, R.; Guezennec, J. Chelating properties of bacterial exopolysaccharides from deep-sea hydrothermal vents. Carbohydr. Polym. 1998, 35, 65-70. [CrossRef]

34. Yan, Z.; Xuliang, F.; Zhilong, Y.; Yahong, L.; Weimin, C. Biosorption of Cu (II) on extracellular polymers from Bacillus sp. F19. J. Environ. Sci. 2008, 20, 1288-1293.

35. Kim, S.-Y.; Kim, J.-H.; Kim, C.-J.; Oh, D.-K. Metal adsorption of the polysaccharide produced from Methylobacterium organophilum. Biotechnol. Lett. 1996, 18, 1161-1164. [CrossRef]

36. Gomaa, E.Z. Production and Characteristics of a Heavy Metals Removing Bioflocculant Produced by Pseudomonas aeruginosa. Pol. J. Microbiol. 2012, 61, 281-289.

37. Maalej, H.; Boisset, C.; Hmidet, N.; Buon, L.; Heyraud, A.; Nasri, M. Purification and structural data of a highly substituted exopolysaccharide from Pseudomonas stutzeri AS22. Carbohydr. Polym. 2014, 112, 404-411. [CrossRef]

38. Wang, L.; Chen, Z.; Yang, J.; Ma, F. Pb(II) biosorption by compound bioflocculant: Performance and mechanism. Desalin. Water Treat. 2015, 53, 421-429. [CrossRef]

39. Can, C.; Jianlong, W. Correlating metal ionic characteristics with biosorption capacity using QSAR model. Chemosphere 2007, 69, 1610-1616. [CrossRef]

40. Vijayaraghavan, K.; Yun, Y.-S. Bacterial biosorbents and biosorption. Biotechnol. Adv. 2008, 26, 266-291. [CrossRef]

41. Torres, C.A.V.; Ferreira, A.R.V.; Freitas, F.; Reis, M.A.M.; Coelhoso, I.; Sousa, I.; Alves, V.D. Rheological studies of the fucose-rich exopolysaccharide FucoPol. Int. J. Biol. Macromol. 2015, 79, 611-617. [CrossRef]

42. Fomina, M.; Gadd, G.M. Biosorption: Current perspectives on concept, definition and application. Bioresour. Technol. 2014, 160, 3-14. [CrossRef]

43. López, A.; Lazaro, N.; Priego, J.M.; Marques, A.M. Effect of $\mathrm{pH}$ on the biosorption of nickel and other heavy metals by Pseudomonas fluorescens 4F39. J. Ind. Microbiol. Biotechnol. 2000, 24, 146-151. [CrossRef]

44. Deng, L.; Su, Y.; Su, H.; Wang, X.; Zhu, X. Sorption and desorption of lead (II) from wastewater by green algae Cladophora fascicularis. J. Hazard. Mater. 2007, 143, 220-225. [CrossRef] [PubMed]

45. Ahemad, M.; Kibret, M. Recent Trends in Microbial Biosorption of Heavy Metals: A Review. Biochem. Mol. Biol. 2013, 1, 19-26. [CrossRef]

46. Subudhi, S.; Batta, N.; Pathak, M.; Bisht, V.; Devi, A.; Lal, B.; Al khulifah, B. Bioflocculant production and biosorption of zinc and lead by a novel bacterial species, Achromobacter sp. TERI-IASST N, isolated from oil refinery waste. Chemosphere 2014, 113, 116-124. [CrossRef]

47. Mota, R.; Rossi, F.; Andrenelli, L.; Pereira, S.B.; De Philippis, R.; Tamagnini, P. Released polysaccharides (RPS) from Cyanothece sp. CCY 0110 as biosorbent for heavy metals bioremediation: Interactions between metals and RPS binding sites. Appl. Microbiol. Biotechnol. 2016, 100, 7765-7775. [CrossRef]

(C) 2020 by the authors. Licensee MDPI, Basel, Switzerland. This article is an open access article distributed under the terms and conditions of the Creative Commons Attribution (CC BY) license (http://creativecommons.org/licenses/by/4.0/). 